\title{
Aggregate resources in the Netherlands
}

\section{M.J. van der Meulen ${ }^{\star}$, S.F. van Gessel \& J.G. Veldkamp}

TN0 Built Environment and Geosciences - Geological Survey of the Netherlands, P.0. Box 80015, 3508 TA Utrecht, the Netherlands.

* Corresponding author. Email: michiel.vandermeulen@tno.nl

Manuscript received: April 2005; accepted: August 2005

\begin{abstract}
We have built a 3D lithological model of the Netherlands, for the purpose of mapping on-land aggregate resources down to $50 \mathrm{~m}$ below the surface. The model consists of voxel cells $(1000 \cdot 1000 \cdot 1 \mathrm{~m})$, with lithological composition and aggregate content estimates as primary attributes. These attributes were derived from $\sim 350,000$ borehole descriptions. Overburdens and intercalations of cohesive or otherwise non-dredgeable materials were taken into account to define geologically exploitable aggregates within the total stock. We arrive at about $520 \cdot 10^{9} \mathrm{~m}^{3}$ of aggregates occurring in the depth range investigated. Some $50 \%$ of this amount is considered geologically exploitable and about $25 \%$ would in principle (but largely not in reality) be accessible. Most aggregates resources ( 98\%) are coarse sand, which is processed for use in concrete, masonry mortars, drains, filters, etc. The total exploitable stock of coarse sand in the depth range investigated amounts to roughly 7500 times the current annual consumption level, and is virtually indepletable. The gravel stock, estimated at some $12 \cdot 10^{9} \mathrm{~m}^{3}$, is small by comparison, and impels a dependency on imports.

Exploitable aggregates occur in all but the coastal provinces. In accordance with current policy changes, the future may show a shift from concentrated production along the upstream Dutch Rhine and Meuse rivers towards a more even distribution of small-sized operations over the country. Fairly large aggregate stocks, that have not yet been exploited to significant extent, are available in the northern extent of the aggregates occurrences.
\end{abstract}

Keywords: Netherlands, sand, gravel, aggregates, resource assessment

\section{Introduction}

Aggregates, i.e. granular mineral materials, are used in construction and by the building-materials industry. Dutch production amounts to about $75 \mathrm{Mt} / \mathrm{a}$ and includes about $50 \mathrm{Mt} / \mathrm{a}$ of fine sand, $20 \mathrm{Mt} / \mathrm{a}$ of coarse sand and $5 \mathrm{Mt} / \mathrm{a}$ of gravel (Van der Meulen et al., in press). The Netherlands are not self-supporting for aggregates; the ever-growing netimport level is currently between 30 and 40 Mt/a. An important reason for this is restricted access to resources. The Dutch population density (481 inhabitants per $\mathrm{km}^{2}$ in 2004) ranks among the highest in the world, and more than $85 \%$ of the Dutch land surface is developed. Land-based aggregates extraction, which usually transforms land into a water body, is therefore prone to raise land-use conflicts and seems to be more controversial than in other countries (Van der Meulen et al., 2003; in press).

The Dutch Ministry of Spatial Planning, Housing and the Environment has recently designed a so-called building raw materials assessment ('bouwgrondstoffentoets'; Anonymous, 2004), in order to arrange for a certain level of access to surface mineral resources. Spatial plans have to be evaluated (i) in terms of the effects on mineral supplies, (ii) for the accessibility of resources of scarce minerals to future generations, and (iii) for the possibilities to embed mineral extraction into projects which have other primary goals (e.g. 
hydraulic engineering, nature development). Note that the Netherlands has very few mineral resources: only aggregates, clay, peat, silica sand and carbonate rocks are quarryable. The assessment defines 'scarce minerals' within this group of minerals, and refers to each of them except for peat, which is not quarried at present, and fine sand. The other minerals can either be geologically scarce (e.g. high quality silica sand), or scarce on the market, mainly because of a restrictive policy for issuing extraction permits (e.g. coarse sand).

The building materials assessment is currently in the process of being adopted by the mineral planning and permitissuing authorities, i.e. the Ministry of Transport, Public Works and Water Management where state waters ('rijkswateren') are concerned, and the provincial administrations in all other cases. Irrespective of the shape the building raw materials assessment will take, it will somehow have to rely on geological information. We present new maps of aggregate resources in the Netherlands, and estimates of the sizes of its stocks down to $50 \mathrm{~m}$ below the surface. Scale and resolution are adapted to a representation on a national scale. The approach taken can however be applied on regional and local scales and, hence, to future building raw materials assessments.

\section{Geological setting}

The Dutch shallow subsurface consists almost entirely of Quaternary clastic deposits, deposited in fluviatile to shallow marine sedimentary environments (Fig. 1,2). Most of the sediments have been supplied by (the predecessors of) the Rhine and Meuse rivers, and by the former Eridanos river system which had a drainage area covering Northern Germany and Scandinavia (De Mulder et al., 2003). They grade, on average, from coarse-grained in the southeast and east towards finegrained in the western and northern parts of the country and the North Sea.

Pleistocene glaciations have shaped the area north of the Rhine-Meuse delta (De Mulder et al., 2003). The course of latest Pleistocene to recent Rhine and Meuse channels has especially been determined by the Saalian ice-sheet and the ice-pushed structures it has produced. The most important icepushed ridges occur in the provinces of Utrecht and Gelderland; the associated ice-scoured glacial basins are located on their concave east and north sides. Sediment distribution south and southeast of the Rhine-Meuse delta, in terms of both quantities and lithofacies, has been governed by north-westward tilting,

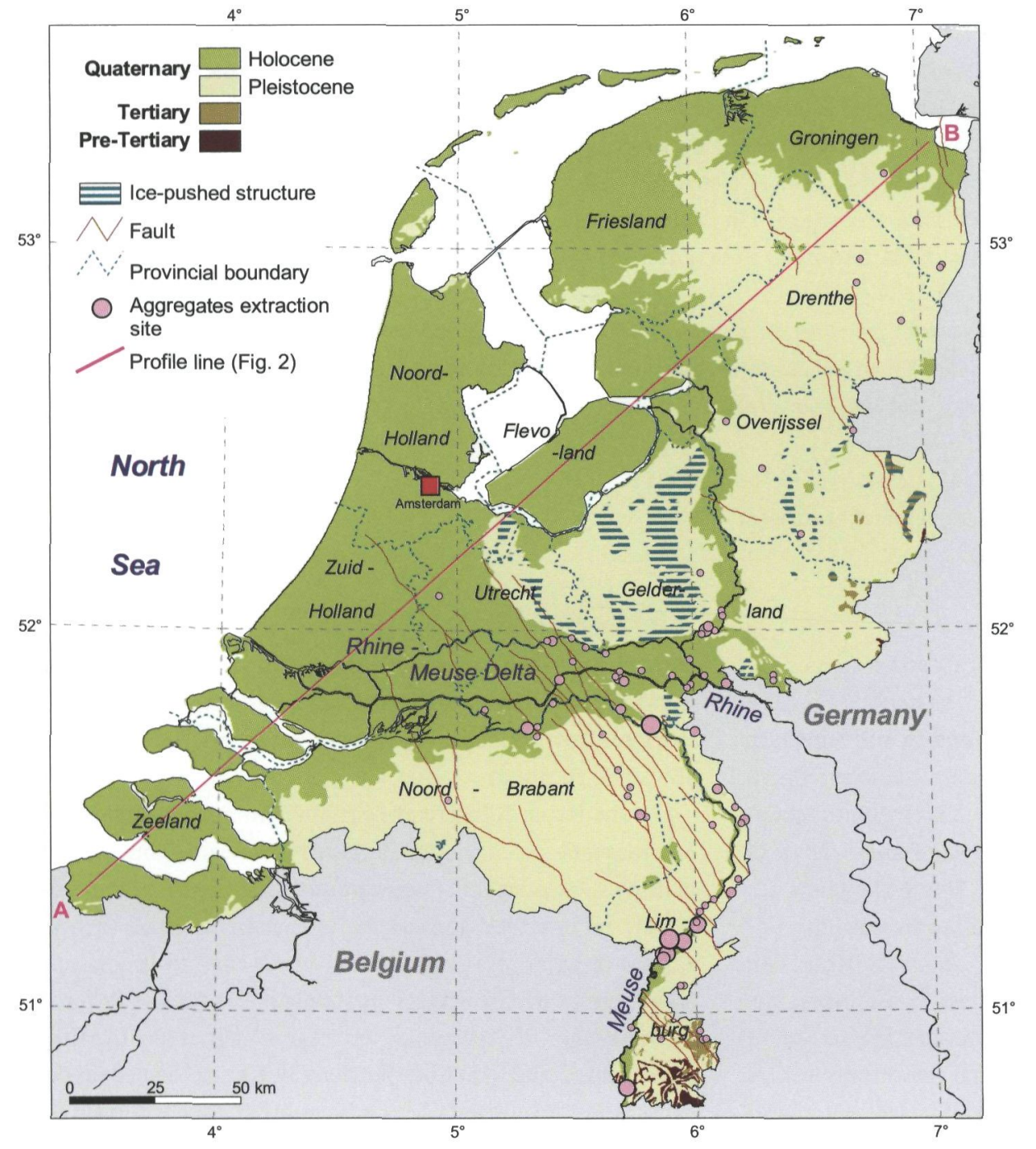

Fig. 1. Geological map of the Netherlands showing provincial boundaries and aggregate extraction sites (active, abandoned and planned; circle size proportional to extraction size). Geological information modified from Weerts et al. (2004). 


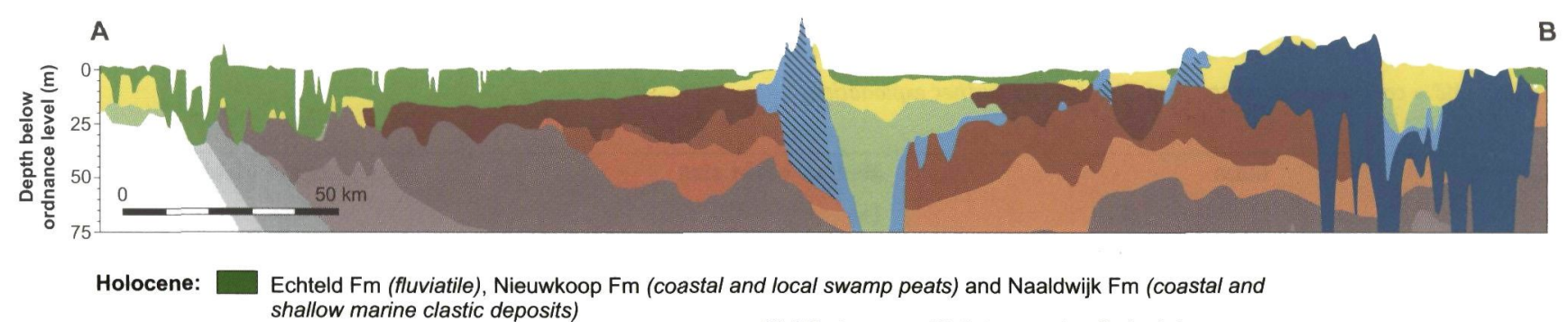

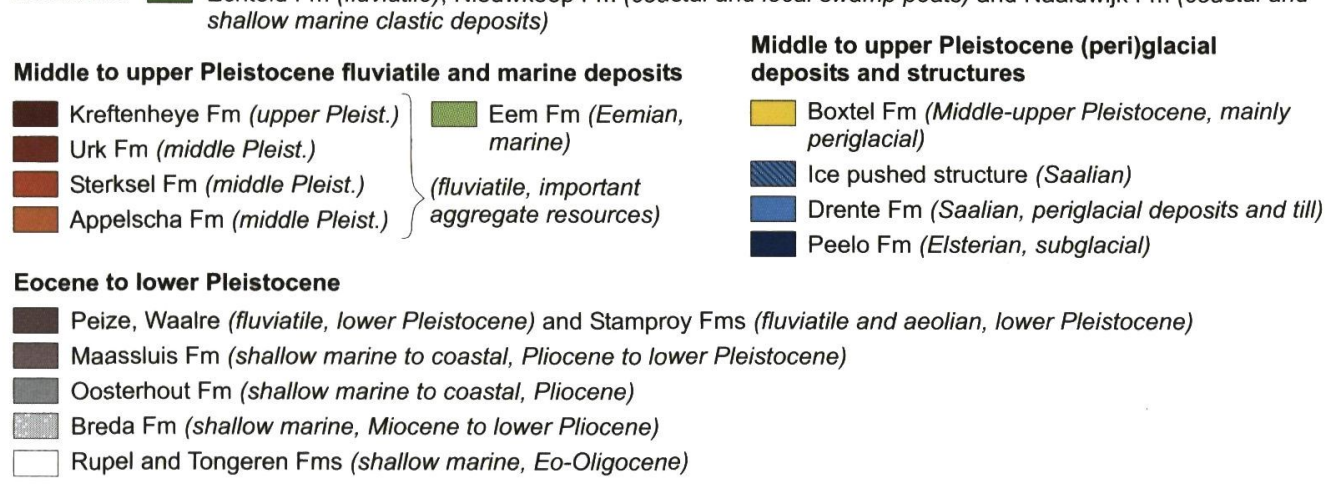

Fig. 2. Geological cross section from Zeeland to Groningen (see Fig. 1 for section line). It has been constructed by intersecting depth grids of formation boundaries $(1: 250,000)$, which have been obtained in the 3D geological mapping program carried out by TNO Built Environment and Geosciences Geological Survey of the Netherlands. All formations referred to are cf. De Mulder et al. (2003).

associated with uplift of the London-Brabant massif, and by NW-SE trending horst-graben structures.

\section{Aggregate commodities: geological data vs. industrial specifications}

\section{The grain size parameter in available data}

Aggregates, except for filling materials, are primarily defined by their grain size distributions. Our aggregates mapping is based on borehole data in DIN0, a digital archive of subsurface data developed and maintained by TNO Built Environment and Geosciences - Geological Survey of the Netherlands (for database specifications see Kooijman, 2003; Peersmann, 2005). Sand descriptions usually include estimated or measured median grain sizes, either as a class (extremely fine, very fine, etc.) or a discrete value (M63, i.e. the median grain size of the sand fraction). Gravel occurrences or admixtures are described in similar ways, although quantifications or classifications occur somewhat less frequently. Only a negligible share of the approx. 380,000 standardized borehole descriptions in DINO includes full grain size distributions, so the sizes of national aggregate stocks can only be approximated.

\section{Aggregate yield calculations}

In order to calculate aggregate yields from lithological data, we have had to use median grain size data pragmatically. Assessments of the application possibilities of sands first requires a distinction between fine and coarse categories (Van der Meulen et al., in press). Fine sand is used as filling material.
As fine sand can be found virtually anywhere in the country and filling sands supplies have never imposed problems, we do not further elaborate on its stocks. In fact, common aggregate definitions usually exclude landfilling materials. Coarse sand is used as an aggregate for more advanced purposes, i.e. for the production of concrete and masonry mortars, in drains, filters etc.

In the Netherlands, coarse sand commodities are usually jointly referred to as 'concrete and mortar sand' ('beton- en metselzand'; NEN, 1991; 1999). A fairly common first order estimator for reserves of concrete and mortar sand is the amount of so-called sand 30/92 that can be produced at a site, i.e. a sand with 30 and 92 cumulative mass percents retaining on the $1 \mathrm{~mm}$ and $250 \mu \mathrm{m}$ sieve, respectively. In approximate accordance with this, we do not consider extremely fine, very fine and moderately fine sands to be concrete and mortar sand resources (Table 1). Secondly, we assume that $50 \%$ of moderately coarse and very coarse sands, i.e. the coarse half of their grain size populations, can be used in concrete and mortar sand. Finally, we assume a $100 \%$ grade for extremely coarse sands, as indeed most concrete and mortar sands would geologically be classified as such. We expect that any type of gravel can be entirely used as or processed into an aggregate: fine gravel as an admixture in concrete and mortar sand, coarse gravel as such. We feel that more sophisticated ways to calculate aggregate yields from lithological descriptions are not relevant on national scale assessments.

\section{Distinguishing between gravel and sand commodities}

A subdivision of aggregates into gravel and sand commodities is hampered by the differences in their industrial and geological 
Table 1. The application of natural sand and gravel as aggregates according to their M63 value. Category and class definitions are cf. Anonymous (1989; 1990); $C M Z=$ concrete and mortar sand. See text for further explanation.

\begin{tabular}{|c|c|c|c|c|c|c|}
\hline \multirow[t]{2}{*}{ Category } & \multirow[t]{2}{*}{ Class } & \multicolumn{3}{|c|}{ Median grain size } & \multicolumn{2}{|c|}{ Aggregate yield } \\
\hline & & $(\geqslant)$ & $(<)$ & & & \\
\hline \multirow[t]{3}{*}{ Fine sand } & Extremely fine & 63 & 105 & $\mu \mathrm{m}$ & $0 \%$ & \\
\hline & Very fine & 105 & 150 & $\mu \mathrm{m}$ & $0 \%$ & \\
\hline & Moderately fine & 150 & 210 & $\mu \mathrm{m}$ & & \\
\hline \multirow[t]{3}{*}{ Coarse sand } & Moderately coarse & 210 & 300 & $\mu \mathrm{m}$ & $50 \%$ & (CMZ) \\
\hline & Very coarse & 300 & 420 & $\mu \mathrm{m}$ & & \\
\hline & Extremely coarse & 420 & -2000 & $\mu \mathrm{m}$ & $100 \%$ & (CMZ) \\
\hline \multirow[t]{3}{*}{ Gravel } & Fine & 2 & 5.6 & $\mathrm{~mm}$ & $100 \%$ & (CMZ, gravel) \\
\hline & Moderately coarse & 5.6 & 16 & $\mathrm{~mm}$ & $100 \%$ & (gravel) \\
\hline & Very Coarse & 16 & 63 & $\mathrm{~mm}$ & & \\
\hline
\end{tabular}

definitions. The Dutch sediment and soil classification system (Anonymous, 1989; 1990) is based on a set of three ternary diagrams. Sediments are classified according to gravel content (diagram 1), organic matter content (diagram 2), and the relative contents of the sand, silt and clay fractions (diagram 3). In this system, gravel is a granular material with $\geqslant 30 \%$ of gravel particles, i.e. particles with a diameter of $\geqslant 2 \mathrm{~mm}$. The more straightforward industrial definition of gravel is a natural granular material with application-dependent lower (generally 4 to $8 \mathrm{~mm}$ ) and upper limits (generally 16 to $32 \mathrm{~mm}$ ) to its grain size distribution. Sand is defined similarly, with a lower limit of 63 to $125 \mu \mathrm{m}$ and an upper limit of 4 to $8 \mathrm{~mm}$. Because of these differences we can not accurately distinguish between gravel and sand commodities on lithological criteria alone. We primarily assess aggregate resources, in which coarse sand and gravel are lumped, and give an indication of gravel resources as a subcategory by applying a geographical search criterion.

\section{Modeling approach}

\section{Model setup and data selection}

As a first step in the resource assessment we have built a 3D-lithological model of the Netherlands (excluding the North Sea) down to a depth of $50 \mathrm{~m}$ below the surface. This depth range comprises aggregate resources that are currently exploited: most aggregates pits are between 25 and $40 \mathrm{~m}$ deep. The model is based on a so-called voxel grid which divides the model space into equal-sized rectangular cells. The model volume covered by a cell is characterized by a number of lithological cell attribute values, which have been either obtained or derived from borehole descriptions in DIN0. We used cells with a surface area of $1000 \cdot 1000 \mathrm{~m}$ and a thickness of $1 \mathrm{~m}$, which resulted in a model of 50 layers of 40,769 cells.

Available borehole descriptions - in principle all of the $\sim 380,000$ in our archives - show a wide range in quality, depending on the drilling method, the original purpose of drilling, drilling personnel qualifications, whether descriptions have been made in the field or in the laboratory, etc. The number of drillings precludes a manual assessment of these factors, so we have used the average thickness of lithological description intervals as a quality proxy. We consider an average thickness $>3 \mathrm{~m}$ to be indicative of insufficient quality for our purposes; such data are discarded from the model data set. The $3 \mathrm{~m}$ limit is a value of experience: from earlier work it is known to exclude the most unreliable cases, such as thirdparty field descriptions of water drillings.

The application of the quality criterion resulted in the selection of 351,161 drillings (Fig. 3). The average number of drillings per $\mathrm{km}^{2}$ (i.e. per cell) decreases from 8.6 for the upper model layer to 0.2 for the lower layer. The average data-quality also decreases with depth: the deeper a drilling, the greater the chance that (cheap) suction or airlift drilling methods were used. As these methods tend to underestimate the shares of the fine fractions, aggregate yields may tend to be increasingly overestimated with depth.

\section{Model characteristics}

The primary model cell attributes are its shares of gravel, sand, clay/loam, peat/gyttja and 'other' material (e.g. the chalk occurring in the southernmost part of the country), calculated from borehole data. The shares of the lithologies that we distinguish were interpolated over cells lacking drilling data, using linear kriging (Fig. 4; e.g. Deutsch \& Journel, 1998). As a next step, aggregate yields for each cell were calculated using the criteria given in Table 1. Aggregate yields were then interpolated over cells which lack grain size information or drilling data altogether, and multiplied with interpolated shares of sand and gravel lithologies in order to obtain absolute values.

The above approach accounts for the grade of aggregate resources. Their exploitability also depends on the thickness 
Fig. 3. Red bars: histogram of the end depth of the drilling data used in our study. Blue bars: the total number of drillings available to a model layer in the depth range indicated. A total of 351,161 standardized borehole descriptions were selected from a total of 380,000 , using a quality proxy explained in the text.

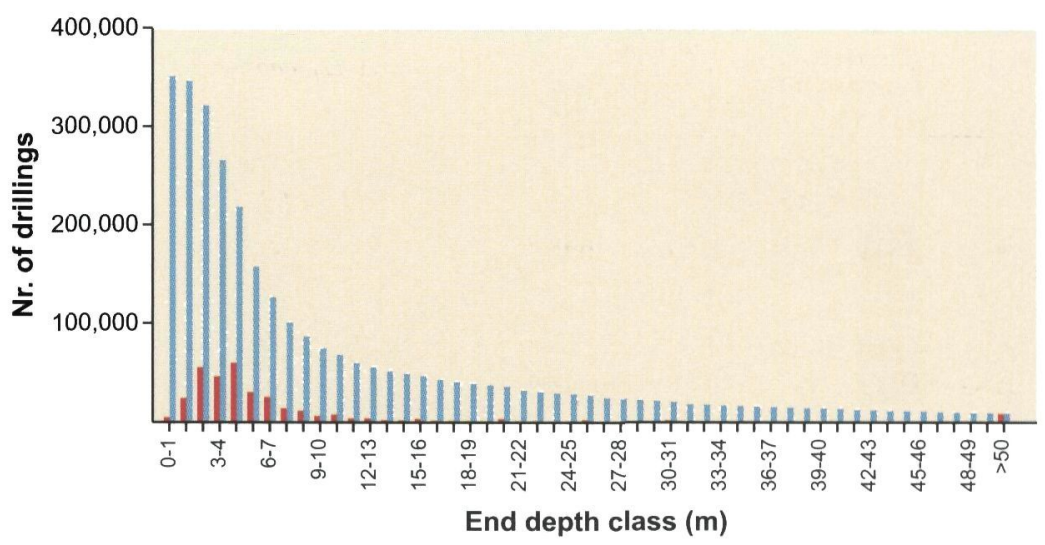

of the overburden that would have to be removed, and of intercalations of fine grained material which may hamper the extraction process (generally some dredging technique). In order to address these factors, routines were used which analyze vertical cell stacks. An overburden routine discards aggregate yields if covered by more than $5 \mathrm{~m}$ of clay, loam, peat or gyttja, i.e. the shares of these materials times the thickness of the cell stack above the first aggregate occurrence. An intercalation criterion, acting from $5 \mathrm{~m}$ below the surface downwards, adds up the amount of these materials present and discards aggregate yields below intercalations with a cumulative thickness of $2 \mathrm{~m}$ or over.

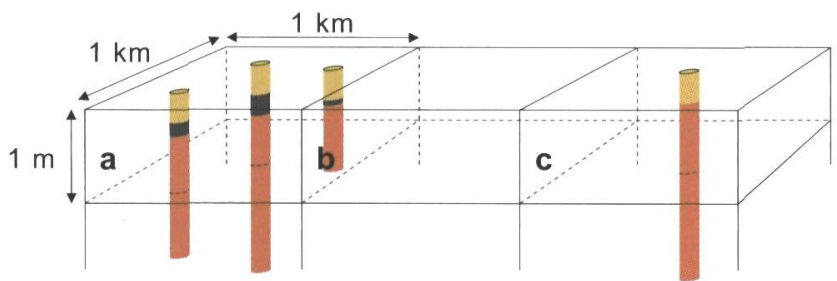

Fig. 4. Model setup, illustrated by three hypothetical cells from the upper model layer. For cell $a$, the shares of distinguished lithologies are obtained by averaging the layer properties in the appropriate depth range of three available drillings. The properties of cell c correspond to those of the one available drilling. The attributes of cell $b$ (i.e. lithology and aggregate yield) are obtained by linear kriging between cell $a$ and $c$. The zero-level in the model space corresponds to land surface.

\section{Results}

\section{General}

Fig. 5 (left 3 panels) shows cumulative aggregates thicknesses down to 10,30 and 50 m below the surface (see Fig. 6 for an appraisal of the underlying model). The results clearly fit the aforementioned general geological trends (Fig. 1, 2). In their northern extent, aggregates predominantly occur in icepushed structures, and are scarcer, absent or covered in the associated glacial basins which generally have fine-grained infillings. In the Rhine-Meuse delta, aggregates occurrences are mainly upper Pleistocene river sands. The east-to-west

decrease of aggregate volumes is a clear reflection of both downstream fining and a westward-thickening overburden. In the south, aggregates occurrences are arranged in the NW-SE trending horst-graben structures.

The total aggregate volume down to $50 \mathrm{~m}$ below the surface is estimated at $\sim 520 \cdot 10^{9} \mathrm{~m}^{3}$ (Fig. 7, 8). Some $240 \cdot 10^{9} \mathrm{~m}^{3}$ of this amount is considered exploitable according to the above geological criteria. Fig. 5 shows that especially the aggregates occurrences in Zuid-Holland are not considered exploitable, due to their overburden. In fact, the westernmost Dutch extraction of concrete and mortar sand occurs just east of the Utrecht - Zuid-Holland boundary, at the westernmost extent of the central Dutch aggregate resources according to our exploitability criteria (middle and lower right panels of Fig. 5). About $80 \%$ of the exploitable aggregate resources occur in 5 out of 12 provinces (i.e., Limburg, Drente, Noord-Brabant, Overijssel and Gelderland; Fig. 9), and about half are situated below built-up areas or nature reserves, and are therefore in principle inaccessible. Note that a $50 \%$ accessibility is probably greatly overestimated. First, we have not taken into account the access limitations presented by scattered buildings and infrastructure in open country. More importantly, various planning restrictions may apply to aggregates extraction, even outside protected nature or landscapes.

\section{Gravel resources}

Most of the Dutch aggregate resources consist of coarse sand, with gravel as an admixture or intercalation. Shading in Fig. 5 corresponds with the occurrence of coarse gravel, which have been mapped for national mineral planning purposes (i.e. for Anonymous, 1994; 2002; note that national mineral planning has been abandoned in 2003; Van der Meulen, 2005). The area encompasses the most important Dutch gravel production sites, that are mainly situated along the upstream Meuse river. The aggregate content of this area down to $50 \mathrm{~m}$ below the surface is about $12 \cdot 10^{9} \mathrm{~m}^{3}$, which amounts to about $25 \%$ of the aggregate resources in Limburg and to about $2 \%$ of the Dutch total. Again, about half of this amount is considered geologically exploitable (Fig. 10). 

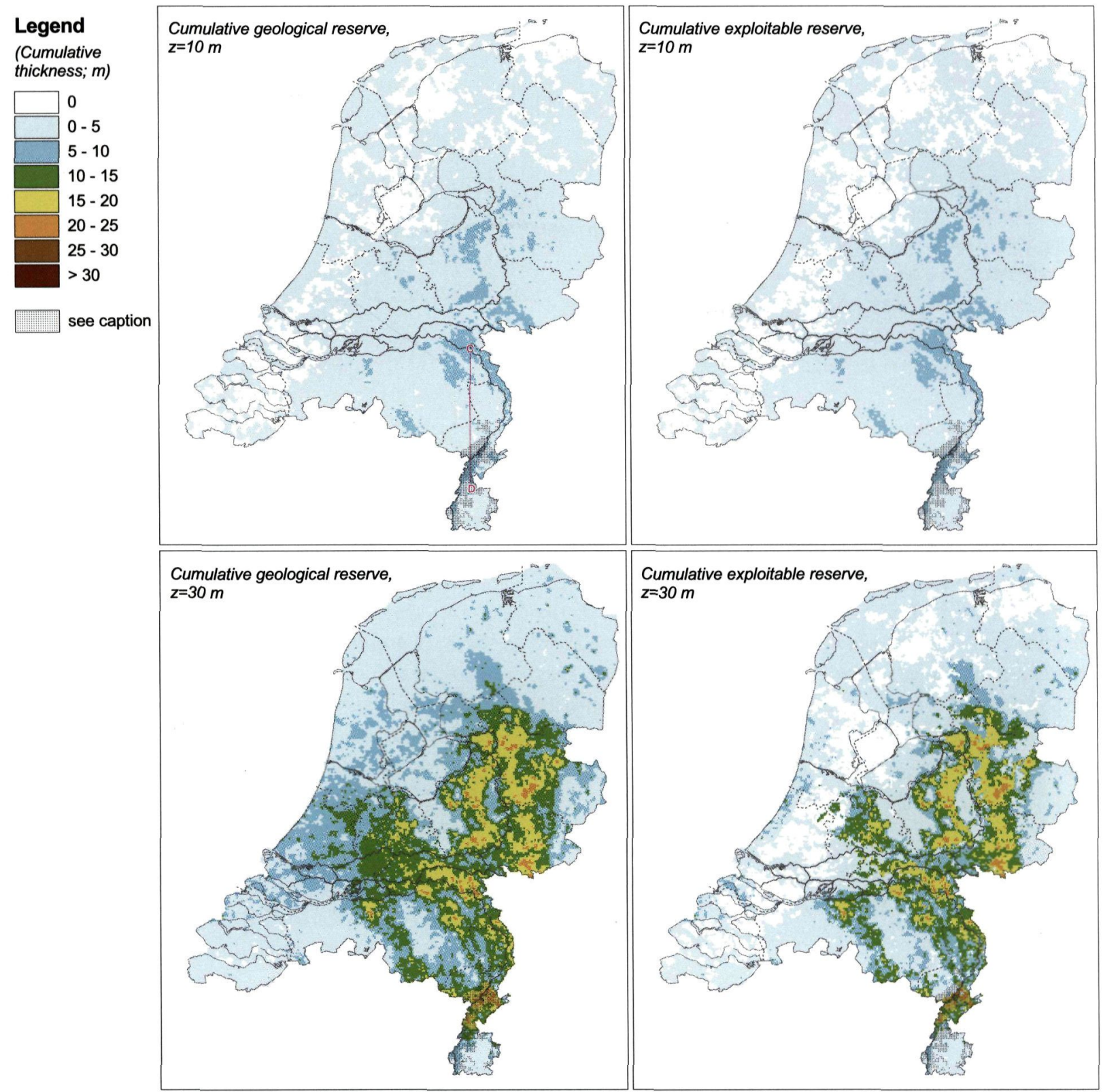

Fig. 5. Aggregate resources down to 10 , 30 and $50 \mathrm{~m}$ below the surface. The left panels show all resources, right panels show exploitable resources, calculated according to criteria explained in the text. Grey shading in southern Limburg indicates the occurrence of coarse gravel (see text for further explanation). Section line $(c-d)$ in the upper left hand panel refers to Fig. 6.

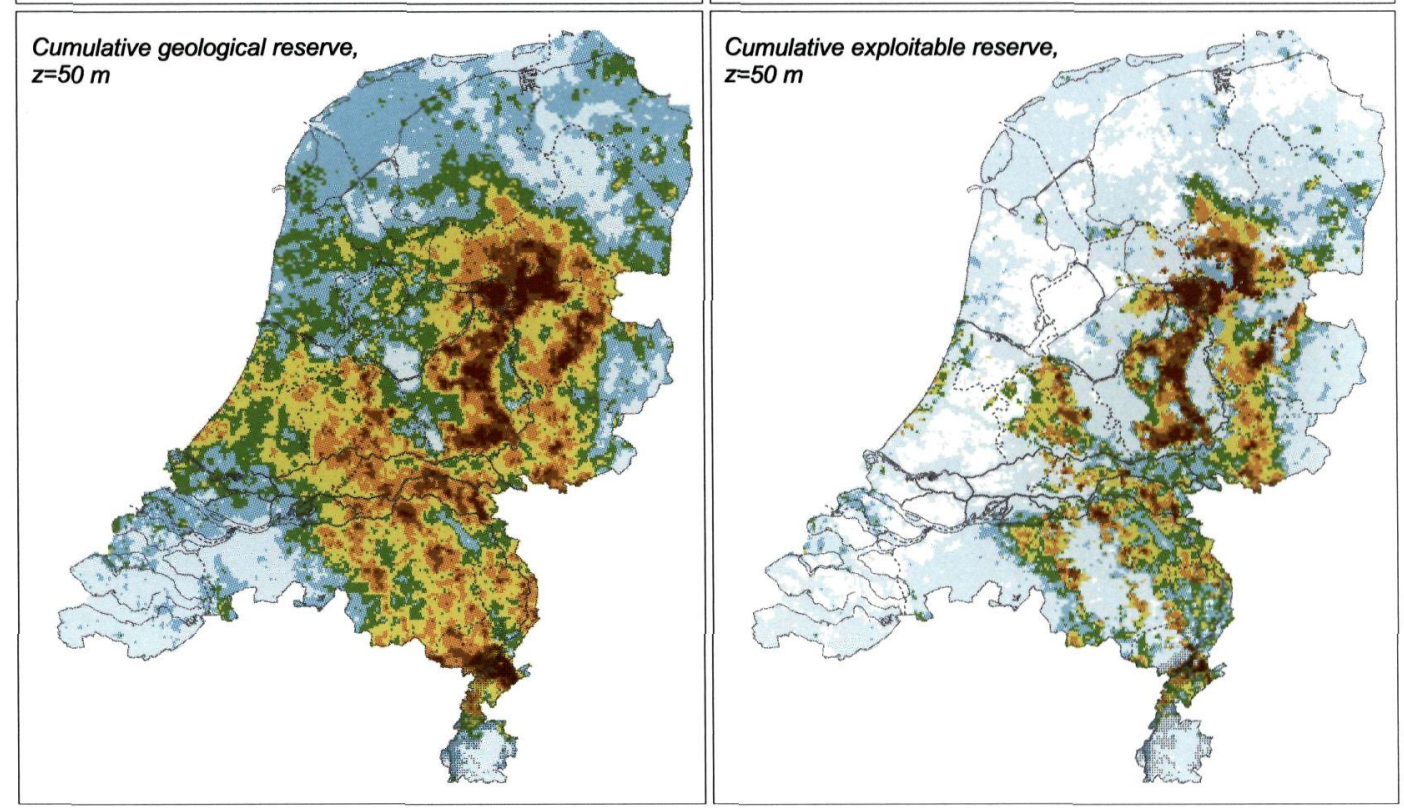


Fig. 6. Cross section through the model space in Limburg (see Fig. 5 for section line). Note that aggregates distribution is consistent with geological structures, even though they have not been imposed to the model.

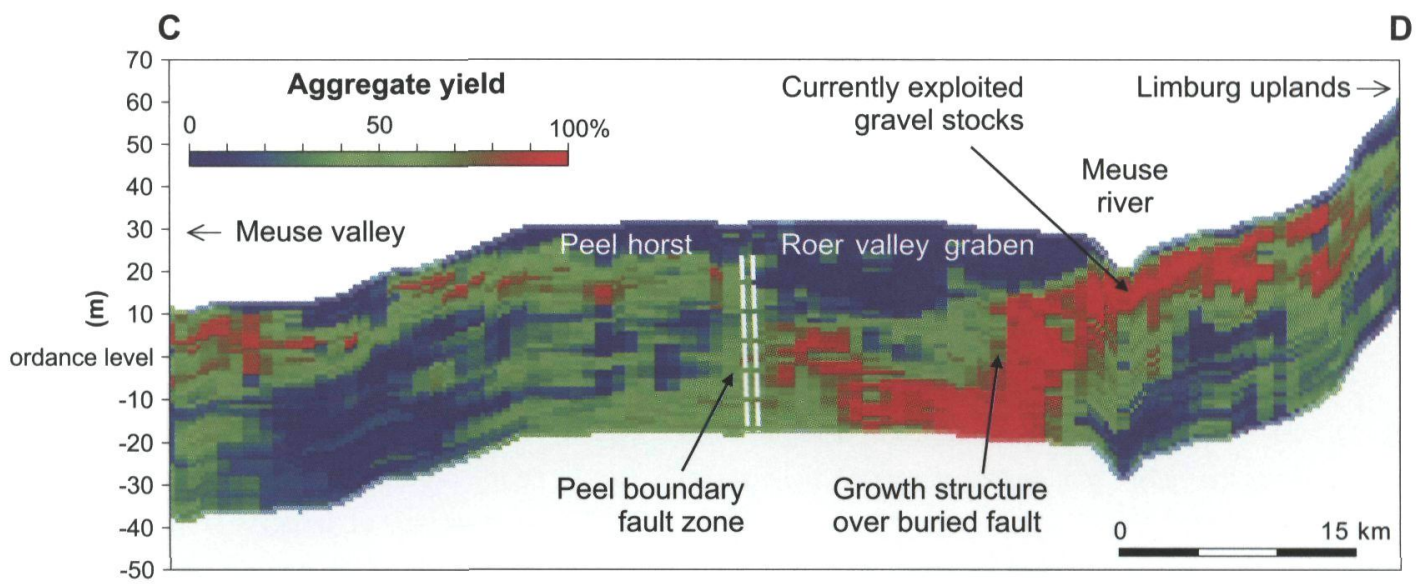

In the south of Limburg, gravel occurs as a relatively thin cover on a substrate of uplifted Upper Cretaceous to Miocene units (Fig. 5, see also Fig. 1). This is clearly reflected in Fig. 11, which shows that the aggregate content decreases with depth, as opposed to the general trend in Fig. 8.

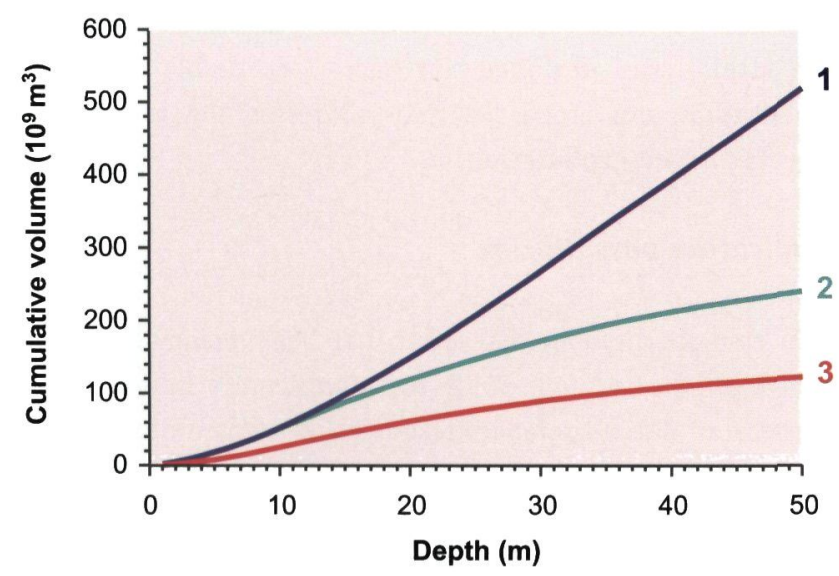

Fig. 7. Cumulative aggregates volumes down to $50 \mathrm{~m}$ below the surface: 1) all aggregates; 2) geologically exploitable aggregates (see text for explanation); 3) idem, disregarding aggregates below built-up areas and protected nature.

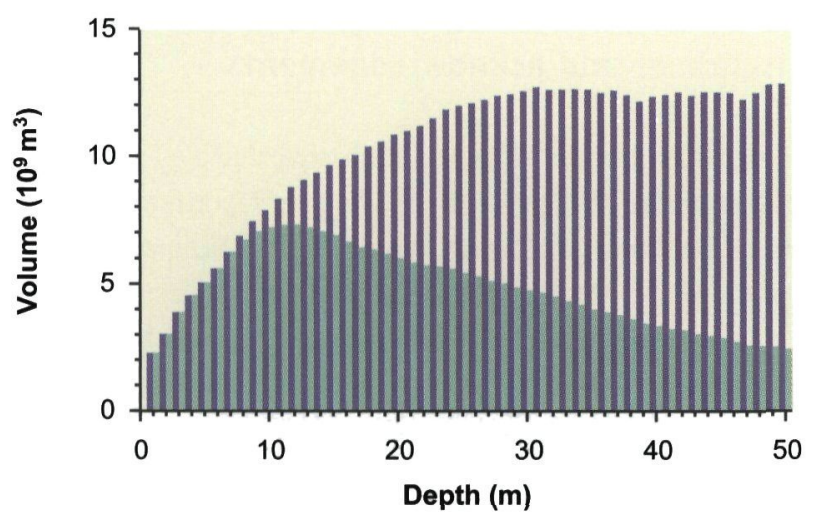

Fig. 8. Aggregates per meter interval down to $50 \mathrm{~m}$ below the surface, blue bars: all aggregates; green bars: geologically exploitable aggregates (see text for explanation).

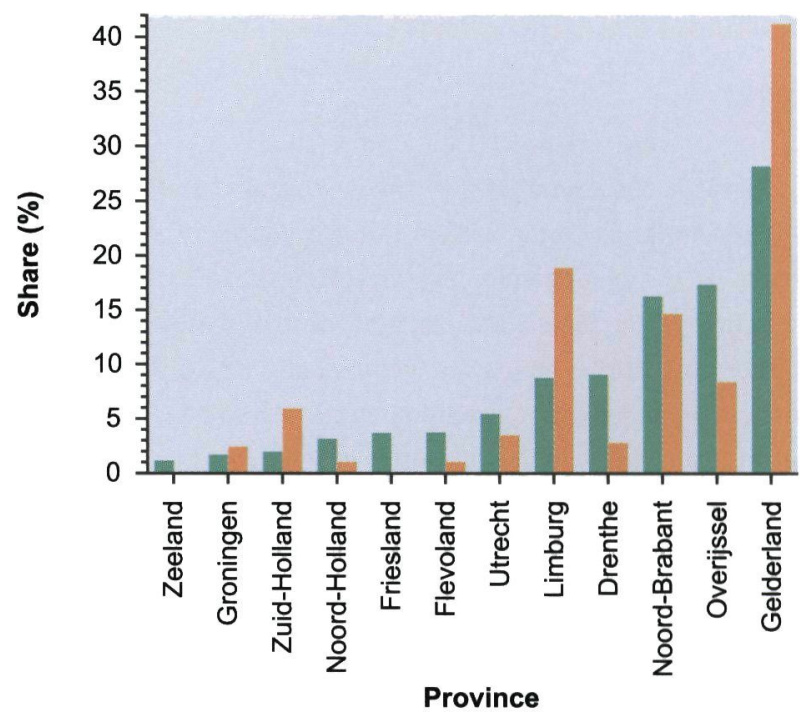

Fig. 9. Green bars: the distribution of geologically exploitable aggregate resources over the provinces (depth range $0-50 \mathrm{~m}$ ). Orange bars represent the distribution of provincial production assignments for concrete and mortar sand, i.e. amounts of product for which permits are to be granted in the period 1999 - 2008. Provincial assignments and resources seem miscorrelated; they have, however, been based on a combination of resource estimates and ease of transport per ship.

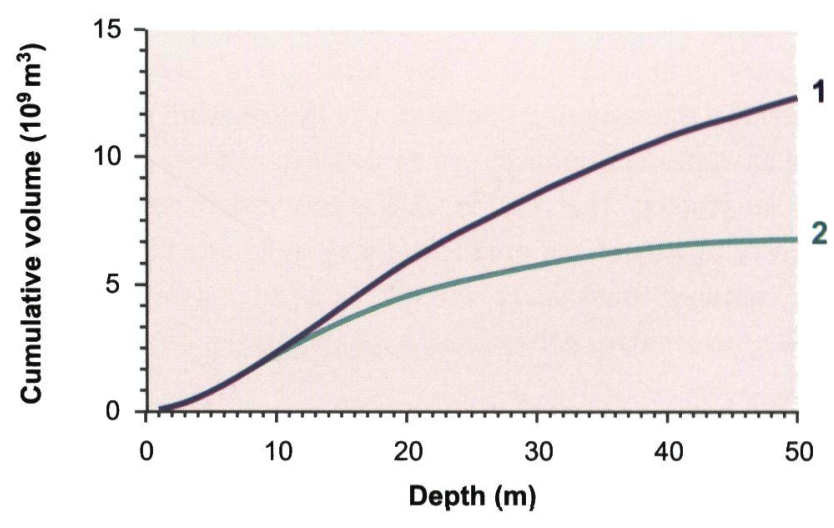

Fig. 10. Cumulative gravel volumes down to $50 \mathrm{~m}$ below the surface: 1) all gravel; 2) geologically exploitable gravel (see text for explanation). 


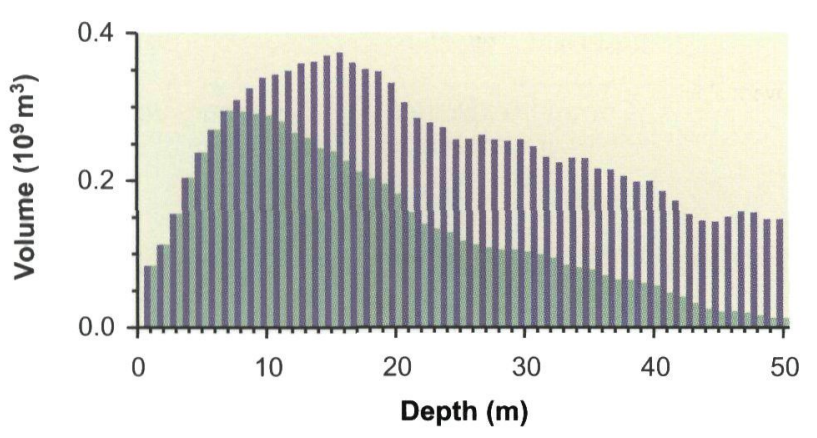

Fig. 11. Gravel per meter interval down to $50 \mathrm{~m}$ below the surface: blue bars all aggregates; green bars geologically exploitable aggregates (see text for explanation).

\section{Concluding remarks}

\section{General}

Aggregates occur abundantly in the eastern and southern parts of the Netherlands. Some $98 \%$ of the aggregates is coarse sand, the size of the geologically exploitable resources corresponds to roughly 7500 times the current annual consumption of concrete and mortar sand. The geologically exploitable gravel resources in southern Limburg amount to some 150 annual consumption equivalents, of which probably only a couple of tens are accessible. Hence, for coarse aggregates, some level of dependency on imports seems inevitable.

\section{Home production}

Mineral planning until the year 2003 has resulted in a concentration of large-scale aggregates extraction sites along the Rhine and Meuse in the provinces of Noord-Brabant, Limburg and Gelderland. These sites were developed for national supplies, i.e. in order to provide provinces lacking resources with aggregates. Under the current policy regime, such large-scale sites will probably not be permitted anymore. The embedding of extraction in projects with other goals, which is both stimulated by the aforementioned building raw materials assessment and envisaged as the future modus operandi by the extractive industry, will most likely also result in a downsizing of individual operations. Altogether, the future home production of aggregates will probably come down to a larger number of smaller projects, that will be more evenly distributed over the country. A part of the production may well shift to Overijssel and southern Drenthe, where fairly large aggregate stocks are present which have not yet been exploited to significant extent.

\section{Future supplies}

As it is for the first time in two decades that production has stopped being regulated, the effects of the recent Dutch policy changes cannot not be predicted. Production figures show that the production of sand aggregates in 2003 was $25 \%$ below the average level of 1996 - 2000. Unpublished provisional data suggest that this unprecedented drop has continued to date, seemingly with no real supply problems. In the coming years, production will probably stabilize at some unknown lower level. Available forecasts suggest that consumption will remain stable or increase slightly (e.g. Van der Meulen et al., in press), so eventually the net imports required may well exceed the production possibilities in the countries that currently export to the Netherlands, especially in the German federal state of North Rhine-Westphalia. All the alternative supply options, e.g., production from lower grade marine resources, deep(er) extraction, or imports from more remote areas, will probably be significantly more expensive.

The question is how much more the Dutch building industry and its commissioners are ultimately prepared to pay for raw materials, knowing that vast resources are in principle available in the country. Large transport distances for low-cost bulk commodities such as sand may also raise some concerns as to the sustainability of the path chosen by Dutch policy makers. Dutch aggregates resources will therefore probably keep being exploited. The embedding concept in the building raw materials assessment was designed for more acceptable forms of exploitation; our study basically addresses the localization aspects of such exploitation.

\section{Application possibilities}

Even though the approach taken has been pragmatic rather than sophisticated, our study has significantly improved our appraisal of Dutch aggregate resources. Most limitations of our modeling methods and yield calculations can be addressed when working on regional scales, handling less data. Examples of this include the quality proxy for borehole descriptions, and the overburden and intercalation criteria, which can both be tuned to regional geological characteristics such as the sedimentary setting and the tectonic history. The approach is intended to be used interactively, allowing aggregate resources and their geological exploitability to be defined by end-users.

\section{Disclaimer and acknowledgements}

Although the authors adhere to its basic principles, this study does not formally comply with the Code for Reporting of Mineral Exploration Results, Mineral Resources and Mineral Reserves (Anonymous, 2001). In the terms of this code, our study would classify as a reconnaissance mineral resource, apt for mineral or spatial planning purposes by the government. Note that our results are not to be used for the purpose of (a) informing investors or potential investors and their advisers or (b) satisfying regulatory requirements. The authors wish to thank their colleague Wim Dubelaar (TNO, Utrecht, NL), and Mike Petterson (BGS, Keyworth, UK) and an anonymous reviewer for helpful suggestions. 


\section{References}

Anonymous, 1989. NEN 5104:1989, Geotechnics; Classification of unconsolidated soil samples. Netherlands Normalization Institute (NEN; Delft, NL): 24 pp.

Anonymous, 1990. NEN 5104:1989/C1, Geotechnics; Classification of unconsolidated soil samples (amended). Netherlands Normalization Institute (NEN; Delft, NL): 1 pp.

Anonymous, 1994. Structuurschema Oppervlaktedelfstoffen, Deel 1, Ontwerp Planologische kernbeslissing (in Dutch). Ministry of Transport, Water Management and Public Works (The Hague, NL): 243 pp.

Anonymous, 2001. Code for reporting of mineral exploration results, mineral resources and mineral reserves (the reporting code). Institution of Mining and Metallurgy (London, UK), European Federation of Geologists (Brussels, B), Geological Society of London, Institute of Geologists of Ireland (Dublin, IE): $34 \mathrm{pp}$.

Anonymous, 2002. 2e Structuurschema Oppervlaktedelfstoffen, Deel 1, Ontwerp Planologische kernbeslissing (in Dutch). Ministry of Transport, Water Management and Public Works (The Hague, NL): 279 pp.

Anonymous, 2004. Nota Ruimte. Ministry of Spatial Planning, Housing and the Environment (The Hague, NL): $50 \mathrm{pp}$.

Braakhekke, W., Litjens, G. \& Winden, A., 2003. Over Winnen - Zandwinning als hefboom (in Dutch). IZGP (Dutch association of sand and gravel producers; Beuningen, NL): 42 pp.

Deutsch, C.v. \& Journel, A.G., 1998. GSLIB Geostatistical software library and user's guide (2nd edition). 0xford University Press (0xford, UK): $369 \mathrm{pp}$.

De Mulder, E.F.J., Geluk, M.C., Ritsema, I., Westerhoff, W.E. \& Wong, Th.E., 2003. De ondergrond van Nederland. Wolters Noordhof (Groningen, NL): 379 pp.

Kooijman, J., 2003. Haalbaarheidsstudie Authentieke Registratie DINO Eindrapportage (in Dutch). Netherlands Institute of Applied Geoscience TNO (Utrecht, NL): $42 \mathrm{pp}$

NEN, 1991. NEN 3835:1991 NL, Mortels voor metselwerk van stenen, blokken of elementen van baksteen, kalkzandsteen, beton en gasbeton (in Dutch). Dutch Normalization Institute (NNI/NEN; Delft, NL): 16 pp.

NEN, 1999. NEN 5905:1997/A1:1999 NL, Toeslagmaterialen voor beton Materialen met een volumieke massa van ten minste $2000 \mathrm{~kg} / \mathrm{m}^{2}$ (in Dutch). Dutch Normalization Institute (NNI/NEN; Delft, NL): 1 pp.

Peersmann, M.R.H.E., 2005. Geo-Informatieprogramma 2005 (in Dutch). Netherlands Institute of Applied Geoscience TNO (Utrecht, NL): 200 pp.

Van der Meulen, M.J., 2005. Sustainable mineral development: possibilities and pitfalls illustrated by the rise and fall of Dutch mineral planning guidance. In: Petterson, M., McEvoy, F. \& Marker, B.R. (eds): Sustainable minerals operations in the developing world. The Geological Society of London, Special Publications 250: 225-232.

Van der Meulen, M.J., Broers, J.W., Hakstege, A.L., Van Heijst, M.W.I.M., Koopmans, T.P.F. \& Pietersen, H.S., in press. Surface Mineral Resources. In: Wong, Th.E., Batjes, D.A.J. \& De Jager, J. (eds): The Geology and geological resources of the Netherlands. Netherlands Institute of Applied Geoscience TNO (Utrecht, NL).

Van der Meulen, M.J., Koopmans, T.P.F. \& Pietersen, H.S., 2003. Construction raw materials policy and supply practices in Northwestern Europe. In: Elsen, J. \& Degryse, P. (eds): Industrial Minerals - Resources, Characteristics and Applications. Aardkundige Mededelingen 13: 19-30.
Weerts, H.J.T., Schokker, J., Rijsdijk, K.F. \& Laban, C., 2004. Geologische overzichtskaart van Nederland / Geological map of the Netherlands. Netherlands Institute of Applied Geoscience TNO (Utrecht, NL). 